\title{
The Conceptions of Pre-service Kindergarten and Elementary school Teachers on Teaching Science and the Nature of Science
}

\author{
Eman Gheith \\ Faculty of Arts and Sciences \\ University of Petra, Jordan \\ Nahil M. Aljaberi \\ Faculty of Arts and Sciences \\ University of Petra, Jordan
}

\begin{abstract}
The study sought to reveal the conceptions of pre-service kindergarten and elementary school teachers on teaching science to children and understanding the nature of science. More specifically, the study aimed to investigate the conception of pre-service teachers on the roles of teachers, which teaching methods they are willing to use in the future when practicing teaching, which difficulties they may face when becoming teachers, and the methods they are willing to put into use when children face difficulties in understanding some of the scientific concepts, in addition to investigating their understanding of the nature of science. In hopes of fulfilling these aims, the researchers have developed a questionnaire consisting of both closed- and open-ended questions. Pre-service teachers' perceptions on the roles of teachers were split into three categories: (1) traditional, (2) constructive, and (3) neutral; their conceptions on understanding the nature of science were split into two categories: (1) traditional and (2) constructive. The study sample consisted of 93 prospective teachers at the University of Petra, majoring in Class Teacher and Kindergarten Teacher. Results have indicated that the study sample had a mixture of constructive and traditional conceptions on teaching science, understanding the nature of science, and the role of teachers. There were no significant differences in pre-service teachers' conceptions on the variables of major and academic year. Furthermore, more than half of the preservice teachers believed that they were adequately qualified to teach science to children, and that experimentation, cooperative learning, and play were the most appropriate teaching methods when teaching science to children.
\end{abstract}

Keywords: Nature of Science, Conception about Teaching Science, Constructive Conceptions, Traditional Conceptions.

\section{INTRODUCTION}

As the last century came to an end, and with the rise of the 21st century, the world came to witness an extraordinary growth in knowledge, as well as a revolution in the field of Information Technology, which has allowed it to overcome geographical distances, rendering the world small, yet highly connected. In the meantime, technology found its way into a wide array of daily-life activities, which has significantly changed the way we learn and perform jobs and activities, making every other educational process nowadays more complicated than ever. Thus, improving teaching, and especially that of science, for all levels of the educational system, has been prioritized worldwide.

Elementary education has received special attention, in comparison with other stages, as it is the cornerstone of all higher stages of education. In the past two decades, science educators 
have prioritized teaching science to elementary school students; they emphasized on the importance of aiding teachers in teaching science to young children, and helping them overcome any difficulties they may encounter in doing so (Harlen, 2006).

Despite the efforts put into teaching science to elementary students, both globally and locally, a number of studies on student conceptions on the natural world have asserted that learning outcomes of science do not meet any of its aspirations, and that teaching sciences requires a shift from transferring knowledge to the student into truly changing students' conception of their surrounding world (Gao \& Watkins, 2002; Ibrahim, 2005).

\section{LITERATURE REVIEW}

In the last four decades, researchers have put great efforts into investigating teachers' conceptions toward learning and teaching, based on the idea that having knowledge of these conceptions is key to comprehensively understanding the processes of learning and teaching used by educators and their teaching practices used inside the classroom when being on the offset of their career paths. Numerous researchers have used the phrase "Traditional vs. Constructive" to signify teachers' conceptions toward this; so while the traditional approach views learning as the process of receiving knowledge from the teacher, the constructive approach, on the other hand, views it as the process of creating knowledge where the learner plays an active role in the learning process through discussion, conversation, and negotiation with others (Chan et al., 2007; Bahcivan \& Kapucu, 2014).

Numerous studies have shown that teachers possess no more than a limited conception regarding their roles as teachers by perceiving learning as an assimilation of knowledge, believing that teaching is to transmit what they know to the students, and assuming that assessment is the process of recalling knowledge that had been previously lectured to the pupils (Tsai, 2002; Porlán\& Del Pozo, 2004). Other studies have shown that science teachers hold misconception regarding crucial aspects of the nature of science, and that such primitive beliefs could be attributed to the fact that pre-service teacher programs do not provide them with sufficient opportunities to develop better understanding of the nature of science, nor to change their preconception and traditional notions toward it (Celik \& Bayrakceken, 2012). These studies have also revealed that teachers' understanding of the nature of science correlates with the teaching activities they resort to in real contexts.

A number of researchers also assert that implementing any real educational changes or innovation largely depend on teachers, as teachers are the main wheel that drives change (Pajares, 1992; Levitt, 2002). Alternatively, various researchers perceive teachers as the main hindrance in the face of change, due to their traditional beliefs (Savasci-Acikalin, 2009) whether it comes to learning and teaching science, or in teachers' understanding of the nature of science (Celik \& Bayrakceken, 2012). Thus, it could be argued that change cannot possibly occur unless teachers are convinced that there is a dire need to realize these changes, and challenge the traditional approach toward learning and teaching science at various educational institutions. Such approaches typically focus on indoctrinating knowledge rather than resorting to constructivism, which, conversely, focuses on the active role of the learner and how the teacher should - in turn - embrace the role of the facilitator of knowledge and organizer of the classroom environment. From this standpoint, one can see why this enormous amount of attention is given to professional preparation of pre-service teachers (especially in kindergartens and elementary schools G1-3), changing teachers' conceptions or beliefs toward learning and teaching science, as well as understanding the nature of science. The emphasis on previously mentioned points is the key point in steering teachers' practices toward more 
consistent and modern teaching approaches in education (Gao \& Watkins 2002). Moreover, Chang )1998) affirms that those teachers' abilities and previous conception regarding the nature of students' learning, teaching sciences, and the cognitive aspect - in addition to the social factors - could stand in the way of them adopting new approaches in teaching.

Furthermore, researchers have intensively focused, in the past two decades, on investigating the conceptions of teachers toward learning and teaching science, and their understanding of the nature of science, in addition to exploring the intellectual framework that steers their behaviors; likewise, their interest has extended to include the professional development of science teachers (Skamp \& Mueller, 2001; Levitt, 2002; Porlán \& Del Pozo, 2004).

Different studies have shown that students who enrolled into teacher preparation programs hold onto preconceived conception on learning and teaching - these conceptions have most likely been formed during their school years (K-12), and are characterized by their stability. Such conceptions can also affect their professional development and ability to develop new knowledge and skills through teacher preparation programs -as these beliefs act as a "filter" through which pre-service teacher may processes the content of courses and classes taught there, as well as any other experiences during their teacher preparation years (Yilmaz-Tuzun, 2008)

Other studies have asserted that a large number of students in teacher preparation programs do not tend to change or alter their conceptions on learning and teaching when they enroll in pre-service teacher preparation programs (Skamp \& Mueller, 2001); on the other hand, a number of studies had findings that were incompatible with the aforementioned, by asserting that being enrolled in pre-service teacher preparation programs at university does indeed change these attitudes (Desli \& Dimitriou, 2013). These studies could contribute to the improvement of pre-service teacher preparation programs, and help pre-service teachers improve their teaching practices, considering how largely a teacher's conceptions might influence his or her judgment, and thus his or her behaviors in the classroom (Pajares, 1992).

These previously discussed conceptions are thus key factors in how teachers implement the curriculum; furthermore, effective teaching practices are derived from teachers' conception on learning and teaching (Skamp \& Mueller, 2001); and it is crucial for these conceptions to undergo basic alterations for the purpose of reforming education. Administrators of teacher preparation programs can no longer ignore teachers' conceptions nor their (lack of) knowledge of the scientific content, as these have a significant impact on their teaching practices in terms of science lesson planning, teaching content, professional development, and methods of presenting knowledge to students (Skamp \& Mueller, 2001)

\section{SIGNIFICANCE OF THE STUDY}

In spite of researchers' interest worldwide in exploring teachers' conceptions on learning and teaching in general, and learning and teaching science and the nature of science in particular especially in the past two decades -, this topic has not been widely studied in Jordan within the knowledge of the researchers, particularly with regard to conceptions of pre-service teachers teaching K-G3 toward teaching sciences and understanding the nature of science.

The significance of this study thus lies in that it highlights the conceptions of pre-service teachers of grades (K-G3) toward teaching science, in addition to exploring their beliefs or conception on the nature of science. This is of great significance given the fact that the few 
studies which investigated the reality of teaching science in Elementary levels in Jordan have shown that teachers' practices in teaching and assessment are more inclined toward the traditional approach, that their professional preparation was insufficient, and that their knowledge of the scientific content suffered deficiencies (Ibrahim, 2005).

The findings of this study could contribute to identifying teachers' conceptions on teaching science and nature of science, which could assist administrators and coordinators of teacher preparation programs at universities in designing effective programs that are concerned with teachers' preconceived conceptions, and take further steps toward steering these into a path that is more consistent with the constructive approach.

\section{PREVIOUS STUDIES}

A number of studies on teachers' beliefs and conceptions on teaching and learning science, as well as their understanding the nature of science, particularly that of Levitt (2002), sought to investigate Elementary school teacher's conceptions and how well these conceptions go hand in hand with the philosophy of reform in teaching science. With 16 teacher participants, the researcher visited the class of each of these and relied on his notes of the classes to conduct interviews with the teachers to gather more data relating to their conceptions on learning and teaching science. The findings revealed that the participants believed that learning and teaching science should be student-centered. Despite the gap that exists between teacher's beliefs and the fundamental aspects of reform, it was clear that teacher's conceptions showed that they were headed into the right direction to lead to comprehensive educational reform.

Moreover, Tsai (2002) performed a study on the beliefs of science teachers learning, teaching, and nature of science, where he attempted to explore the correlation between the three using a study sample consisting of 37 teachers who hold Bachelor degrees in Chemistry and Physics, and who teach students in Grades 7-12. Data was collected through individual interviews, resulting in teachers' responses being categorized into three dimensions: Traditional, Transitional, and Constructive. The findings revealed that more than half the sample held traditional beliefs.

In addition, Az-Zadajali (2006) conducted a study in the Sultanate of Oman, aiming to investigate the beliefs of science teachers when using the constructive theory, and how these could be influenced by the teachers' sex or years of experience; furthermore, the researcher sought to investigate the relation between teachers' beliefs and their teaching practices by using a 5-level scale for beliefs, in addition to her use of performance-rating cards. The findings revealed a mean of 3.49 for science teachers using the constructive method, which appears to be on a neutral level; furthermore, significant differences were found on the sex variable and in favor of female teachers. In addition, the findings showed that teachers rarely ever apply constructive theories in teaching, and that no correlation exists between teachers' beliefs and their classroom practices.

Al-Omary (2006) conducted a study to investigate science teachers' beliefs on the nature of science, the learning and teaching of science, and how these related to teachers' teaching practices, using semi-constructed and individual interviews, which he conducted with 17 male and female teachers. The researcher categorized teachers' beliefs on learning and teaching into Constructive, Transitional, or Traditional; furthermore, he video-recorded 4 classes given by each of the teachers in the sample. His findings revealed that $35 \%$ of the sample had traditional beliefs, $18 \%$ had constructive beliefs, and $47 \%$ had a mixture of both. As for teachers' beliefs on 
the nature of science, results indicated that $35 \%$ had traditional beliefs, $24 \%$ had constructive beliefs, and $41 \%$ had a mixture of the two.

In addition, Chan et al. (2007) investigated student/teacher conceptions on learning and teaching in Singapore through investigating the effects of variables including preparation programs, sex, race, age, and field of study, where a sample consisting of 313 student/teachers in Singapore completed a questionnaire. Findings indicated that student teachers have constructive and traditional conceptions on learning and teaching, even though they were more inclined toward the former. Furthermore, findings pointed at statistically significant differences in two variables: field of study and race.

Around the same period, Yilmaz-Tuzun (2008) conducted a study investigating the beliefs of elementary school pre-service teachers on teaching science through a scale especially designed for the purpose of the study to reveal teachers' abilities in implementing both traditional and modern teaching methods, in addition to their abilities in using assessment strategies, class management techniques, and methods of teaching course material. In a sample of 166 preservice teachers enrolled in 3 different American universities, results revealed statistical significance among teachers' confidence levels and their assessment techniques, classroom management, teaching methods, and a number of courses which students attended (whether they were on science and/or teaching methods).

In addition, Al-Amoush et al. (2013) investigated the different aspects of beliefs of chemistry pre/in-service teachers through analyzing their drawings of classroom situations, in addition to using qualitative research methods to investigate pre-service teachers' beliefs on classroom arrangement and teaching aims, as well as epistemological beliefs. Results have shown that these beliefs were in between traditional teacher-centered ones and constructive studentcentered ones.

In relation to teachers' beliefs on the nature of science, a study conducted by Hamaideh (2013) aimed at identifying the level of students' understanding of the nature of science at Palestinian universities, as juniors or seniors, and to establish the impact of the university attended, academic year, and different courses taken on the nature of science on the aforementioned. The study concluded that their level of understanding was not of sufficient depth.

Furthermore, Ankoush (2014) explored the beliefs of teachers in Palestine on learning/teaching science and sources for acquiring it using a questionnaire especially designed for measuring teachers' beliefs, in addition to interviews aiming to identify the sources (and nature) of these beliefs. Ankoush (2014) concluded that 59\% of science teachers hold a mix of traditional and constructive beliefs; in addition to that, teachers acquire these beliefs from different sources, which include the surrounding social environment, colleagues, previous teachers, higher education, technology, media, etc.

Desli \& Dimitriou (2013) investigated the beliefs of pre-service science and mathematics teachers in pre- and elementary school levels in a sample consisting of 93 kindergarten and 80 elementary school student- teachers. The findings indicated that teaching science and mathematics to kindergarten children is different than teaching both subjects to elementary school students. Moreover, the researchers have found that using inquiry and investigation, in addition to the use of practical methods that depend on experimentation, can yield the best outcomes when teaching both subjects to students. 


\section{STUDY PROBLEM}

Educators have long focused on teaching science to elementary students; however, the actual performed practices of science teaching at this level do not meet the aspirations and goals of the educational system in Jordan. Thus, improving the learning and teaching of science in Jordan is not possible if teachers' conceptions remain ignored - as copious studies have found that teachers' classroom practices are consistent with their conceptions about learning and teaching science (Hashweh, 1996; Levitt, 2002;Al-Omary, 2006); whilst other studies have found that teachers' practices are affected by numerous factors in addition to the beliefs and conception, which include social and physical constructs, cultural standards, and epistemological orientation (Hancock \& Gallard, 2004)

Since only a small number of studies tackled this issue for the elementary level in particular, this paper aims to identify and explore the beliefs or conception of pre-service elementary school teachers toward learning and teaching sciences, as well as understanding the nature of science. To be more specific, the research aims to answer the following questions:

1. What are the conceptions of pre-service teachers majoring in Class Teacher and Kindergarten Teacher toward the roles of teachers in teaching science? Do these differ in accordance with the major or academic year?

2. What are the teaching methods these pre-service teachers will put into use when practicing teaching?

3. What difficulties do these pre-service teachers expect to face when teaching science in the future?

4. What procedure will these pre-service teachers take if students fail to understand a certain scientific concept?

5. How qualified are these pre-service teachers in teaching science from their own viewpoint?

6. What are the conceptions pre-service teachers majoring in Class Teacher and Kindergarten Teacher toward the understanding the nature of science? Do these differ in accordance with the major or academic year?

7. Is there a correlation between pre-service teachers' beliefs or conceptions regarding the role of the teacher, and understanding the nature of science?

\section{STUDY TERMINOLOGY}

Conceptions: A set of ideas, beliefs, and points of view held by student teachers on learning, teaching, and the nature of science. This set of ideas influences their teaching practices in different teaching situations, and are measured through student teachers' answers to the questionnaire.

Traditional Conceptions: A set of ideas and convictions on learning and teaching, which view learning as an assimilation of knowledge, and regard students as the passive receivers of knowledge while teachers are the source. Such ideas embrace the notions of gradual and accumulative learning, believing that teaching is to inform students of facts already known to the teacher.

Constructive Conceptions: A set of ideas and convictions on learning and teaching which view learning as the creation of knowledge. In this sit, acquiring knowledge by the learner is done through interpretation, argumentation, and social negotiation, and occurs when the learner links a new knowledge to their previously existing cognitive structure, and that 
teaching requires that teachers provide students with an active and effective learning environment, which prompts active learning in students.

Neutral Conceptions: A set of ideas and convictions on learning and teaching which consider the teacher's role to be providing students with fun activities, while putting great efforts in planning and in selecting activities which suit the students, in addition to constantly striving toward self-improvement as a teacher.

Conceptions of Understanding the Nature of Science: A set of opinions, beliefs, viewpoints, and ideas, which an individual has formed regarding the nature of scientific knowledge and the advancement of science.

Traditional Approach to the Nature of Science: A set of ideas and conceptions, which regard scientific knowledge as objective, logical, and unaffected by the beliefs of scientists. Such knowledge reflects reality and is not affected by cultural or social contexts. In this view, scientists attain scientific knowledge through the scientific methods, and theories become laws when proven.

Constructive Approach to the Nature of Science: A set of ideas on the nature of science, which regard scientific knowledge as reliable, yet temporary and subject to change. Additionally, this approach views scientific knowledge as relative and not free of personal bias. Accordingly, scientists attain scientific knowledge in different ways, and scientific observation is affected by scientists' opinions - there is no link between laws and theories.

\section{METHODOLOGY}

The Researchers have designed a questionnaire consisting of two parts for the purpose of this study; (1) the first aimed to collect information on the study sample, which included what university major they were enrolled in, their current academic year, and the courses they attended on methods of teaching science; (2) the second part aimed to identify pre-service Class Teacher and kindergarten Teachers' conceptions toward teaching science to young children and toward the nature of science. Furthermore, the second part of the questionnaire consisted of seven questions, of which two were open-ended. The open-ended questions aimed to reveal the conceptions of pre-service Class Teacher and kindergarten teachers on teaching science, in regards to the difficulties they may encounter when teaching it in the future, and the procedures they would resort to when their students face difficulties in understanding certain concepts; furthermore, the close-ended questions required the participants to choose one or more answers from multiple choices - these were used to explore the sample's conceptions regarding their level of qualification for teaching science in the future and implementing effective methods of teaching science in to children in grades K-G3. The seventh question included a group of phrases which the participants were required to rate on a 5-point Likert Scale (where " 5 " = strongly agree, and " 1 " = strongly disagree) - this last item aimed to measure teachers' roles and their level of understanding of the nature of science.

This questionnaire was designed after conducting literature review on teachers' conceptions on learning and teaching sciences. Teacher roles were categorized into three main dimensions: (a) traditional, (b) constructive, and (c) neutral; while teachers' understandings of the nature of science were categorized into two dimensions: (a) traditional and (b) constructive. Numerous items were designed and prepared in order to measure the aforementioned dimensions. The questionnaire was presented to a group of specialists in teacher preparation 
programs to ensure their suitability for measured students' conceptions on teacher roles and understanding the nature of science, as well as to ensure that they are linguistically and structurally correct. Ultimately, the final form of the questionnaire included 5 items measuring the roles of traditional teachers, 9 measuring the roles of constructive teachers, and 7 measuring those of neutral teachers; in addition to 21 items measuring the traditional understanding of science, and 19 measuring its constructive understanding .

The reliability coefficient of the role of teacher questionnaire was calculated using Cronbach's alpha, which gave a reliability coefficient of 0.74 for the traditional, constructive and neutral dimensions; and a reliability coefficient of 0.89 for the overall questionnaire on pre-service teachers' understanding of the nature of science. Additionally, the first and second dimensions (traditional and constructive) had reliability coefficients of 0.83 and 0.80 respectively. These values are acceptable for research purposes.

The study sample consisted of 93 female students enrolled at University of Petra at the Educational Sciences Department, majoring in (a Class Teacher and Kindergarten teachers' with 71 students $(76.3 \%$ of the sample) majoring in the former, and 22 in the latter $(23.7 \%$ of the sample). As for academic level, 9 were freshmen (9.7\%), 33 sophomores (35.5\%), 31 juniors (33.3\%), and 20 seniors $(23.6 \%)$.

\section{RESULTS}

To answer the first question ("What are the conceptions of pre-service teachers majoring in Class Teacher and Kindergarten Teacher toward the roles of teachers in teaching science")? Do these differ in accordance with the major or academic year? Mean and standard deviation values of the study sample's scores on questionnaire were calculated as shown in Tables (1). 
Table 1: Mean and standard deviation values of study samples' scores on the teachers' roles in teaching science questionnaire

\begin{tabular}{|c|c|c|c|c|}
\hline & $\begin{array}{l}\text { Role of the } \\
\text { Teacher }\end{array}$ & Statement & Mean & S.D. \\
\hline 3 & Traditional & Caring for students and providing them with a safe environment & 4.60 & 0.57 \\
\hline 2 & Traditional & Guiding students toward achieving the desired goals & 4.41 & 0.58 \\
\hline 1 & Traditional & Providing students with scientific knowledge & 4.40 & 0.61 \\
\hline 4 & Traditional & Managing the classroom through setting precise rules and regulations & 4.33 & 0.68 \\
\hline \multirow[t]{2}{*}{5} & Traditional & Shaping students' minds & 3.58 & 1.17 \\
\hline & & Average & 4.26 & 0.39 \\
\hline 7 & Constructive & Encouraging students to engage in the learning process & 4.72 & 0.50 \\
\hline 6 & Constructive & Providing students with the opportunity to explore & 4.69 & 0.49 \\
\hline 10 & Constructive & $\begin{array}{l}\text { Enhancing students' learning through creating an appropriate learning } \\
\text { environment }\end{array}$ & 4.58 & 0.61 \\
\hline 8 & Constructive & Facilitating and supporting students' learning & 4.57 & 0.61 \\
\hline 11 & Constructive & $\begin{array}{l}\text { Providing students with the opportunity to interact with their peers and the } \\
\text { teacher }\end{array}$ & 4.52 & 0.52 \\
\hline 12 & Constructive & Revealing students' preconception to enhance their learning & 4.38 & 0.72 \\
\hline 9 & Constructive & $\begin{array}{l}\text { Encouraging students to construct knowledge by themselves with the help of } \\
\text { the teacher }\end{array}$ & 4.34 & 0.73 \\
\hline 14 & Constructive & $\begin{array}{l}\text { Looking for what students desire to learn and designing plans in accordance } \\
\text { with that }\end{array}$ & 4.04 & 1.00 \\
\hline \multirow[t]{2}{*}{13} & Constructive & Giving students the freedom to choose what they'd like to learn & 3.91 & 0.99 \\
\hline & & e c & 4.42 & 0.38 \\
\hline 18 & Neutral & $\begin{array}{l}\text { Boosting students' motivation to learn through providing them with enjoyable } \\
\text { activities while showing enthusiasm and positive attitudes toward science }\end{array}$ & 4.68 & 0.53 \\
\hline 15 & Neutral & Supplementing the class with fun and enjoyment & 4.62 & 0.67 \\
\hline 17 & Neutral & Developing one's skills in teaching the scientific content & 4.44 & 0.63 \\
\hline 20 & Neutral & Developing one's self to become a life-long learner & 4.34 & 0.73 \\
\hline 19 & Neutral & $\begin{array}{l}\text { Expanding one's knowledge of science and how to teach science through } \\
\text { acquiring more experience and attending workshops in science field }\end{array}$ & 4.33 & 0.68 \\
\hline 16 & Neutral & Placing great efforts into lesson planning & 4.25 & 0.87 \\
\hline 21 & Neutral & $\begin{array}{l}\text { Investing long periods of time in studying scientific subjects and choosing } \\
\text { appropriate activities and supplements for teaching scientific concepts }\end{array}$ & 3.75 & 0.95 \\
\hline & & Average & 4.35 & 0.45 \\
\hline
\end{tabular}

Tables (1) show that pre-service teachers have a mix of conceptions: traditional, constructive and neutral with respect to their roles as teachers in teaching science. However, these conceptions are more inclined toward constructivism, where the mean values of the Participants' scores in teacher roles on the constructive, neutral, and traditional dimensions were $4.42,4.35$, and 4.26 respectively.

Data in Table (1) indicates that the study sample hold onto a mixture of traditional, constructive, and neutral conceptions on teachers' roles in teaching science, meaning that they believe the role of the teacher is to encourage students to participate in the learning process and ensuring they are given the necessary opportunities for exploration, while boosting their learning through a suitable learning environment and allowing them to engage with classmates and the teacher, in addition to investigating misconception held by them - all which are consistent with the constructive approach. Moreover, it indicates that, since teachers also hold neutral conceptions, the role of the teacher is to motivate learners through engaging them in entertaining and enjoyable activities all while striving toward academic and professional selfdevelopment. Furthermore, teachers have also adopted traditional conceptions in a number of aspects, emphasizing the importance of nurturing students and providing them with a safe environment and scientific knowledge, and steering them toward achieving desired outcomes. 
To investigate the impact of university major (Class Teacher and Kindergarten Teacher) on the conceptions of pre-service teachers on teachers' roles, mean and standard deviation values of the study sample's scores were calculated, as shown in Table (2).

Table 2: Means and standard deviations of the sample's scores on the teacher roles questionnaire by their university major

\begin{tabular}{|c|c|c|c|c|c|c|c|}
\hline & \multirow[t]{2}{*}{ Dimension } & \multicolumn{2}{|c|}{$\begin{array}{l}\text { Class Teacher } \\
\mathrm{N}=71\end{array}$} & \multicolumn{2}{|c|}{$\begin{array}{l}\text { Kindergarten } \\
\text { Teacher } \\
\mathrm{N}=22\end{array}$} & \multirow[t]{2}{*}{$\mathrm{T}$} & \multirow{2}{*}{$\begin{array}{l}\text { Sig. } \\
\alpha\end{array}$} \\
\hline & & $\mathrm{M}$ & SD & $\mathrm{M}$ & SD & & \\
\hline \multirow{3}{*}{ Teachers' Roles } & Traditional & 4.27 & 0.36 & 4.25 & 0.49 & 0.135 & 0.89 \\
\hline & Constructive & 4.40 & 0.40 & 4.48 & 0.30 & -0.798 & 0.427 \\
\hline & Neutral & 4.34 & 0.46 & 4.35 & 0.40 & -0.10 & 0.921 \\
\hline
\end{tabular}

According to the data in Table (2), students of both majors have a mixture of traditional and constructive conceptions, where these are more constructively inclined and less traditionally inclined. On a closer view, it is evident that pre-service teachers' mean values in both majors were very similar on the traditional dimension at 4.27 for Class Teacher and 4.25 for Kindergarten Teacher. In the constructive dimension, pre-service Class Teacher had a mean of 4.48, slightly higher than Kindergarten Teacher (4.40).

To investigate whether these differences in the study sample mean values for both majors were statistically significant, a statistical t-test was performed as shown in Table (2). Findings indicated that there were no significant differences.

To look into the impact of academic year on teachers' conceptions, mean and standard deviation values of the study sample's scores in different academic years were calculated. Results are shown in Table (3).

Table 3: Means and standard deviations of the study sample's scores on the teacher roles questionnaire on the academic year variable

\begin{tabular}{|c|c|c|c|c|c|c|c|c|c|c|c|}
\hline \multicolumn{2}{|l|}{ academic year } & \multicolumn{2}{|c|}{ Freshmen $\mathrm{N}=9$} & \multicolumn{2}{|c|}{ Sophomores $\mathrm{N}=33$} & \multicolumn{2}{|c|}{$\begin{array}{l}\text { Juniors } \\
\mathrm{N}=31\end{array}$} & \multicolumn{2}{|c|}{$\begin{array}{l}\text { Seniors } \\
\mathrm{N}=20\end{array}$} & \multirow[b]{2}{*}{$\mathrm{F}$} & \multirow[b]{2}{*}{ Sig. } \\
\hline & Dimension & $\mathrm{M}$ & SD & $\mathrm{M}$ & SD & $\mathrm{M}$ & SD & $\mathrm{M}$ & SD & & \\
\hline \multirow[t]{3}{*}{ Teacher roles } & Traditional & 4.07 & 0.56 & 4.31 & 0.38 & 4.29 & 0.35 & 4.24 & 0.40 & 0.97 & 0.41 \\
\hline & Constructive & 4.51 & 0.27 & 4.45 & 0.40 & 4.39 & 0.37 & 4.39 & 0.41 & 0.36 & 0.78 \\
\hline & Neutral & 4.34 & 0.46 & 4.29 & 0.51 & 4.34 & 0.42 & 4.46 & 0.37 & 0.58 & 0.63 \\
\hline
\end{tabular}

Findings in Table (3) indicate that student teachers in different academic levels held a mixture of all three conceptions regarding teachers' roles in teaching science. However, pre-service teachers' conceptions become noticeably less inclined toward constructivism in later years of study. Data in the aforementioned table show how student teachers' mean values on the teachers' roles questionnaire increase alongside their academic year on the traditional dimension in the first 3 years of academic life; conversely, their mean values on the constructive dimension decrease as they spend more time at university, meaning that academic advancement at university does not seem to contribute to making student teachers' conceptions on teaching any more constructive. On the other hand, mean values of sophomores and seniors were equal (3.92). Moreover, mean values of the neutral dimension increased as students advanced through their academic years from freshmen to seniors. 
To investigate whether these differences in the study sample mean values for academic year variable were statistically significant, ANOVA test was performed, and $\mathrm{F}$ values are shown in Table (3). Findings indicated that there were no significant differences.

To answer the second question ("What are the teaching methods these pre-service teachers will put into use when practicing teaching?"), the frequencies and percentage of studentteachers' responses to what science teaching methods they will put into use when teaching grades (K-G3) were calculated. Table (4) shows these findings:

Table 4: Frequencies and percentage of study sample participants' responses to what teaching methods they will put into use when teaching grades (K-G3)

\begin{tabular}{|l|l|l|l|}
\hline No. & Teaching method & $\begin{array}{l}\text { Class Teacher } \\
\text { Freq. }(\%)\end{array}$ & Kindergarten Teacher \\
\hline 1 & Experimentation & $52(73 \%)$ & $16(73 \%)$ \\
\hline 2 & Collaborative Learning & $39(55 \%)$ & $8(36 \%)$ \\
\hline 3 & Playing & $31(44 \%)$ & $10(45 \%)$ \\
\hline 4 & Scientific Story Telling & $25(35 \%)$ & $9(41 \%)$ \\
\hline 5 & Activity-based teaching & $21(30 \%)$ & $7(32 \%)$ \\
\hline 6 & Linking knowledge to reality & $18(25 \%)$ & $6(27 \%)$ \\
\hline 7 & Developing Previous Knowledge & $12(17 \%)$ & $3(14 \%)$ \\
\hline 8 & Computer Programs and Applications & $5(7 \%)$ & $1(4 \%)$ \\
\hline 9 & Lecturing & $4(6 \%)$ & $5(23 \%)$ \\
\hline 10 & The Integrated Approach & $2(3 \%)$ & $1(4 \%)$ \\
\hline 11 & Learning Cycle & $2(3 \%)$ & $0(0 \%)$ \\
\hline
\end{tabular}

Table (4) demonstrates that pre-service primary teachers believe that "Experimentation" is one method that educators ought to use when teaching grades G1-G3, followed by "Collaborative Learning", "Playing", and "Scientific Story Telling". On the other hand, preservice kindergarten teachers believed that "Experimentation" is one method that should mostly be used, followed by "Playing", "Scientific Story Telling", and "Activity-Based Learning" respectively. It should also be noted the "Learning Cycle" was the least used science teaching method.

To answer the third question ("What difficulties do these pre-service teachers expect to face when teaching science in the future?"), the frequencies of pre-service teachers responses to what difficulties they expect to face when teaching science to grades (K-G3) were calculated. Table (5) shows these findings

Table 5: Frequencies and percentage of study sample participants' responses to what difficulties they expect to face when teaching science to grades (K-G3)

\begin{tabular}{|l|l|l|}
\hline No. & Difficulties & Freq. (\%) \\
\hline 1 & Being unable to take the individual difference between students into account & $49(53 \%)$ \\
\hline 2 & Lack of resources or equipment at the school & $48(52 \%)$ \\
\hline 3 & Not possessing sufficient teaching strategies & $42(45 \%)$ \\
\hline 4 & Not possessing classroom management skills & $23(25 \%)$ \\
\hline 5 & Students getting low test scores and not possessing basic skills (3Rs) & $23(25 \%)$ \\
\hline 6 & Attracting students' attention and motivation & $21(23 \%)$ \\
\hline 7 & Crowded and difficult curriculum & $20(22 \%)$ \\
\hline 8 & Having large numbers of students in the classroom & $17(18 \%)$ \\
\hline 9 & Classroom environment (desks, size of study hall or room) & $17(18 \%)$ \\
\hline 10 & Not possessing sufficient academic knowledge as a teacher & $13(14 \%)$ \\
\hline 11 & Negative attitudes of some students toward science & $11(12 \%)$ \\
\hline 12 & Difficulty of performing experiments & $9(10 \%)$ \\
\hline 13 & Other & $4(4 \%)$ \\
\hline
\end{tabular}


The difficulties student teachers may face could be categorized into (1) difficulties regarding teacher-preparation programs, and (2) difficulties related to the science curriculum and school environment. One of the most important difficulties they expect to face is related to teacher preparation programs; considering that teachers' inability to take students' individual differences into account came in first (53\%), followed by not possessing sufficient strategies in teaching $(45 \%)$, being unable to manage the classroom $(25 \%)$, being unable to motivate students to learn (23\%), and finally, not possessing sufficient scientific knowledge (14\%). In regards to difficulties related to factors associated with the science curriculum, school, or students, the participants first listed the lack of resources and equipment available at the school (52\%), followed by students' low test scores and their lack of basic skills (25\%), crowded and difficult curriculums (22\%), overcrowded numbers of students in a single classroom (18\%), unsuitable classroom environment (18\%), and finally students' negative attitudes toward science (12\%).

To answer the fourth question ("What procedure will these pre-service teachers take if students fail to understand a certain scientific concept?"), the frequencies of responses of the study sample were calculated as shown in Table (6).

Table 6: Frequencies and percentage of responses of the study sample on what procedures they will take when their students face difficulties in understanding a scientific concept

\begin{tabular}{|l|l|l|}
\hline No. & Item & Freq (\%) \\
\hline 1 & $\begin{array}{l}\text { Using alternative teaching methods such as playing, story-telling, } \\
\text { engaging in activities, field trips, etc }\end{array}$ & $82(89 \%)$ \\
\hline 2 & Repeating the lesson & $80(86 \%)$ \\
\hline 3 & Using teaching aids & $51(55 \%)$ \\
\hline 4 & Providing students the opportunity to perform hands-on experiments & $31(33 \%)$ \\
\hline 5 & Implementing modern technologies, such as applications or movies & $25(27 \%)$ \\
\hline 6 & Linking the subject to real life & $25(27 \%)$ \\
\hline 7 & Collaborative Learning & $17(18 \%$ \\
\hline 8 & Allowing the student extra time & $16(17 \%)$ \\
\hline
\end{tabular}

The findings shown in Table (6) indicate that pre-service teachers may resort to a number of methods to help clarify a scientific concept that students may face difficulties in understanding; the most common response given was the use of alternative teaching methods such as playing, story-telling, engaging in activities, or planning field trips (89\%), followed by repeating the lesson (86\%), or using teaching aids (55\%); alternatively, the least preferred methods were allowing students to conduct or perform hands-on activities(33\%), using modern technology such as computer applications or movies (27\%), or relating the subject at hand to real life situations $(27 \%)$, of which using collaborative learning (18\%) and individualized learning came in last $(17 \%)$.

To answer the fifth question ("How qualified are these pre-service teachers in teaching science from their own viewpoint?"), the frequencies of each response were calculated on a scale of four self-reported levels (excellent, good, fair, weak). Table (7) demonstrates these results:

Table 7: Frequencies of each response given by the study sample on how qualified they were to teach science

\begin{tabular}{|l|l|l|}
\hline Level of qualified & Frequency counts & Percentage (\%) \\
\hline Excellent & 7 & $\% 7$ \\
\hline Good & 44 & $\% 47$ \\
\hline Fair & 34 & $\% 37$ \\
\hline Weak & 8 & $\% 9$ \\
\hline
\end{tabular}


Results in Table (7) indicate that 54\% of the study sample believed they had good or excellent qualifications to teach science to students in grades K-G3; while 37\% believed they were only fairly qualified, in addition to $9 \%$ who believed they were not properly qualified to teach science to children.

To answer the sixth question (What are the conceptions pre-service teachers majoring in Class Teacher and Kindergarten Teacher toward the understanding the nature of science)? Do these differ in accordance with the major or academic year? Mean and standard deviation values of the study sample's scores on nature of science questionnaire were calculated as shown in Tables (8).

Table 8: Mean and standard deviation values of study samples' scores on the understanding of the nature of science questionnaire

\begin{tabular}{|c|c|c|c|c|}
\hline & & & & \\
\hline No & & Statement & Mean & S.D. \\
\hline 8 & Traditional & $\begin{array}{l}\text { Development of scientific knowledge is achieved through scientific } \\
\text { experimentation. }\end{array}$ & 4.43 & 0.68 \\
\hline 7 & Traditional & $\begin{array}{l}\text { A researcher or scientists should not hold onto any preconceived notions or } \\
\text { any kind of bias regarding the results of a scientific experiment prior to } \\
\text { conducting it, to ensure that the experiment is scientific and correctly } \\
\text { performed. }\end{array}$ & 4.24 & 0.71 \\
\hline 16 & Traditional & Scientific knowledge is always accumulative, and develops in this way. & 4.23 & 0.72 \\
\hline 2 & Traditional & $\begin{array}{l}\text { Science is interested in facts, and makes use of facts in proving scientific } \\
\text { theories. }\end{array}$ & 4.17 & 0.64 \\
\hline 4 & Traditional & $\begin{array}{l}\text { Scientists depend on organized scientific methods when seeking to reach } \\
\text { scientific knowledge, to ensure that they will get the correct answers. }\end{array}$ & 4.09 & 0.79 \\
\hline 10 & Traditional & $\begin{array}{l}\text { Scientific laws may be proven as true, but scientific theories are subject to } \\
\text { change or alteration, and may be falsified at any time. }\end{array}$ & 4.09 & 0.83 \\
\hline 11 & Traditional & $\begin{array}{l}\text { Scientific theories are ideas and hypothesis that require further } \\
\text { experimentation, and have not been proven in a way satisfactory to the } \\
\text { scientific community. }\end{array}$ & 4.09 & 0.76 \\
\hline 9 & Traditional & $\begin{array}{l}\text { If a scientist or researcher gets the same results over and over again, then } \\
\text { this indicates that a certain law or truth has been proven right. }\end{array}$ & 4.08 & 0.88 \\
\hline 12 & Traditional & $\begin{array}{l}\text { Scientists use imagination when gathering data, but no further creativity } \\
\text { should exist after the data has been collected, since a scientist must be } \\
\text { objective and unbiased. }\end{array}$ & 4.04 & 0.76 \\
\hline 20 & Traditional & $\begin{array}{l}\text { Scientists are objective because they rely on the scientific method in } \\
\text { conducting research or solving everyday problems. }\end{array}$ & 4.04 & 0.79 \\
\hline 14 & Traditional & $\begin{array}{l}\text { Scientists arrive at different conclusions regarding the same phenomena } \\
\text { because they were not there to witness it when it first occurred (such as the } \\
\text { extinction of dinosaurs). }\end{array}$ & 4 & 0.72 \\
\hline 15 & Traditional & $\begin{array}{l}\text { Since science is based on facts that do not differ according to geographic } \\
\text { location, then science is not affected by any local cultural traditions. }\end{array}$ & 3.92 & 1.11 \\
\hline 3 & Traditional & Scientific facts are true and unchangeable. & 3.85 & 0.95 \\
\hline 6 & Traditional & $\begin{array}{l}\text { A scientific experiment is a series of steps that are done in order to prove a } \\
\text { certain theory. }\end{array}$ & 3.85 & 0.93 \\
\hline 17 & Traditional & $\begin{array}{l}\text { Scientific knowledge is published in order for other scientists to save their } \\
\text { efforts. }\end{array}$ & 3.69 & 1.08 \\
\hline 18 & Traditional & The producing of knowledge requires skills, which only scientists possess. & 3.47 & 1.03 \\
\hline 13 & Traditional & $\begin{array}{l}\text { Scientists have a trusted knowledge of the composition of atoms because } \\
\text { they were able to see these atoms using electronic microscopes. }\end{array}$ & 3.44 & 1.26 \\
\hline 1 & Traditional & $\begin{array}{l}\text { Science is characterized by its clarity where there is no room for personal } \\
\text { opinions or points of view, and it is rather more factual. }\end{array}$ & 3.4 & 1.23 \\
\hline 19 & Traditional & The scientific model is unrelated to scientific theories. & 3.2 & 1.24 \\
\hline 21 & Traditional & $\begin{array}{l}\text { Science is not influenced by culture \& society because scientific knowledge } \\
\text { is global, and does not change in relation to the geographical location. }\end{array}$ & 3.12 & 1.15 \\
\hline
\end{tabular}


Gjeotj. E. \& Aljaberi, N.M. (2017). The conceptons of Pre-Service Kindergarten and Elementary school Teahcers on Teaching Scinece and the Nature of Schience. Advances in Social Sciences Research Journal, 4(2) 1-19.

\begin{tabular}{|c|c|c|c|c|}
\hline 5 & Traditional & Science requires a scientific method that is based on experimentation. & 3.08 & 1.3 \\
\hline & & $\begin{array}{ll}y & \text { Average }\end{array}$ & 3.85 & 0.48 \\
\hline 29 & Constructive & $\begin{array}{l}\text { Scientific experiments do not always provide us with conclusive results } \\
\text { since there are numerous scientific theories, which cannot be directly tested } \\
\text { through experimentation. }\end{array}$ & 4.49 & 0.6 \\
\hline 34 & Constructive & $\begin{array}{l}\text { Scientists have relied on indirect methods in studying the composition of } \\
\text { atoms. }\end{array}$ & 4.45 & 0.58 \\
\hline 31 & Constructive & $\begin{array}{l}\text { The scientific law describes the quantitative relationships between the } \\
\text { variables while the theory presents an explanation for the world we live in. }\end{array}$ & 4.34 & 0.65 \\
\hline 33 & Constructive & $\begin{array}{l}\text { Logic plays a significant role in the scientific process, but formulating new } \\
\text { ideas and explaining results requires great skill in imagination and } \\
\text { creativity. }\end{array}$ & 4.29 & 0.64 \\
\hline 35 & Constructive & $\begin{array}{l}\text { Scientists present different explanations for the same phenomenon or event } \\
\text { because their previous experiences, teaching, and cultural and social } \\
\text { backgrounds differ. }\end{array}$ & 4.27 & 0.84 \\
\hline 23 & Constructive & $\begin{array}{l}\text { The development or growth of scientific knowledge depends on tangible } \\
\text { real-life observations. }\end{array}$ & 4.15 & 0.74 \\
\hline 28 & Constructive & $\begin{array}{l}\text { In planning for and preparing a scientific experiment, the individual ought to } \\
\text { have an idea of what will happen so that he or she could design the } \\
\text { experiment properly. }\end{array}$ & 4.13 & 0.73 \\
\hline 38 & Constructive & $\begin{array}{l}\text { Scientific knowledge is published in order for it to be validated and accepted } \\
\text { in the scientific society. }\end{array}$ & 4.12 & 0.73 \\
\hline 37 & Constructive & $\begin{array}{l}\text { Scientific knowledge sometimes grows accumulatively, and sometimes } \\
\text { revolutionarily. }\end{array}$ & 3.99 & 0.9 \\
\hline 32 & Constructive & $\begin{array}{l}\text { Scientific theories are theoretical hypotheses and ideas which are supported } \\
\text { by evidence, which are also constantly attempted to be falsified }\end{array}$ & 3.97 & 0.89 \\
\hline 30 & Constructive & $\begin{array}{l}\text { Scientific knowledge undergoes constant change and alteration in light of } \\
\text { new evidence, which is why we never knowledge that is } 100 \% \text { true. }\end{array}$ & 3.96 & 0.9 \\
\hline 26 & Constructive & $\begin{array}{l}\text { Scientific experimentation implies a sort of validity or falseness to scientific } \\
\text { theories or hypotheses, but does not prove them. }\end{array}$ & 3.94 & 0.93 \\
\hline 22 & Constructive & Science aims to move from the tangible world to the world of ideas. & 3.89 & 0.94 \\
\hline 36 & Constructive & $\begin{array}{l}\text { Society's culture affects scientific ideas, as evident by the fact that the } \\
\text { beliefs of the Church in Europe had a significant effect on scientific and } \\
\text { technological advancement in the past. }\end{array}$ & 3.88 & 0.93 \\
\hline 39 & Constructive & $\begin{array}{l}\text { Scientists use models in an attempt at embodying theories into a tangible, } \\
\text { easy-to-understand reality. }\end{array}$ & 3.86 & 1.07 \\
\hline 24 & Constructive & All forms of scientific knowledge are subject to change and alteration. & 3.82 & 0.83 \\
\hline 27 & Constructive & $\begin{array}{l}\text { The scientific experiment is a process conducted under specific } \\
\text { circumstances in aims to test the object at hand (such as a law or hypothesis) } \\
\text { while keeping all other factors under control. }\end{array}$ & 3.82 & 1.18 \\
\hline 40 & Constructive & $\begin{array}{l}\text { Social and cultural factors affect how well a society accepts scientific ideas; } \\
\text { for examples, Germans support Darwin's theory of evolution for cultural } \\
\text { and social considerations, while it is widely rejected among the French. }\end{array}$ & 3.69 & 1.14 \\
\hline \multirow[t]{2}{*}{25} & Constructive & $\begin{array}{l}\text { Scientists attain scientific knowledge through numerous methods, which } \\
\text { include intuition, insight, and chance - and not merely through following the } \\
\text { scientific method. }\end{array}$ & 3.44 & 1.18 \\
\hline & & $\begin{array}{ll} & \text { Average }\end{array}$ & 4.00 & 0.38 \\
\hline
\end{tabular}

Tables (8) show that pre-service teachers have a mix of conceptions (both tradition and constructive) regarding their understanding the nature of science. However, these conceptions are more inclined toward constructivism, where the mean values of the Participants' mean scores on understanding the nature of science on the constructive and traditional dimensions were 4.00 and 3.85 respectively. They believe that scientific experimentation does not always produce conclusive answers, that scientists resort to indirect methods in studying the composition of the atom, and that a law describes the relationship between variables while theories provide an explanation for phenomenon and events surrounding us, which are all consistent with constructive conceptions. Furthermore, teachers believe that scientific knowledge is achieved through scientific experimentation, and that knowledge always grows 
accumulatively, in addition to perceiving that a scientist should not have any pre-conceived notions on the results of his or her experiment in hopes of ensuring that it remains scientific and valid, which is consistent with the traditional approach.

To investigate the impact of university major on the conceptions of student teachers on understanding the nature of science, mean and standard deviation values of the sample's scores were calculated, as shown in Table (9).

Table 9: Means and standard deviations of the sample's scores on the understanding the nature of science questionnaire by their university major

\begin{tabular}{|l|l|l|l|l|l|l|l|}
\hline & \multirow{2}{*}{\begin{tabular}{l} 
Dimension \\
\cline { 3 - 9 }
\end{tabular}} & \multicolumn{2}{|l|}{$\begin{array}{l}\text { Class Teacher } \\
\mathrm{N}=71\end{array}$} & $\begin{array}{l}\text { Kindergarten } \\
\text { teacher } \\
\mathrm{N}=22\end{array}$ & $\mathrm{~T}$ & \multirow{2}{*}{ Sig. } \\
\cline { 3 - 10 } & & $\mathrm{M}$ & $\mathrm{SD}$ & $\mathrm{M}$ & $\mathrm{SD}$ & $\mathrm{t}$ & $\alpha$ \\
\hline $\begin{array}{l}\text { Understanding the } \\
\text { Nature of Science }\end{array}$ & Traditional & 3.84 & 0.48 & 3.89 & 0.50 & -0.485 & 0.629 \\
\cline { 2 - 9 } & Constructive & 4.03 & 0.39 & 3.89 & 0.36 & 1.488 & 0.140 \\
\hline
\end{tabular}

According to the data in Table (9), students of both majors have a mixture of traditional and constructive conceptions, where these are more constructively inclined and less traditionally inclined in both majors. Mean values on understanding the nature of science were higher in Class Teacher on the constructive dimension (at 4.03) than those of Kindergarten Teacher (at 3.89) with an offset of 0.14 . On the traditional dimension, however, mean values were close, marking 3.84 for Class Teacher, and 3.89 for Kindergarten Teacher.

To investigate whether these differences in the sample mean values for both majors were statistically significant, a statistical t-test was performed as shown in Table (9). Findings indicated that there were no significant differences.

To look into the impact of academic year on teachers' conceptions, mean and standard deviation values of the sample's mean scores in different academic years were calculated. Results are shown in Table (10).

Table 10: Means and standard deviations of the study sample's scores on understanding the nature of science questionnaire on the academic year variable

\begin{tabular}{|c|c|c|c|c|c|c|c|c|c|c|c|}
\hline \multicolumn{2}{|l|}{ academic year } & \multicolumn{2}{|c|}{$\begin{array}{l}\text { Freshmen } \\
\mathrm{N}=9\end{array}$} & \multicolumn{2}{|c|}{$\begin{array}{l}\text { Sophomores } \\
\mathrm{N}=33\end{array}$} & \multicolumn{2}{|c|}{$\begin{array}{l}\text { Juniors } \\
\mathrm{N}=31\end{array}$} & \multicolumn{2}{|c|}{$\begin{array}{l}\text { Seniors } \\
\mathrm{N}=20\end{array}$} & \multicolumn{2}{|c|}{ F $\quad$ Sig. } \\
\hline Unde & & 3.63 & 0.49 & 3.92 & 0.44 & 3.80 & 0.50 & 3.92 & 0.51 & 1.15 & 0.33 \\
\hline & Constructive & 3.80 & 0.51 & 4.03 & 0.32 & 4.00 & 0.42 & 4.05 & 0.38 & 1.02 & 0.39 \\
\hline
\end{tabular}

Findings in Table (10) indicate that students' mean values on the traditional dimension increased as students transitioned from their freshmen (3.63) to their sophomore (3.92) year, then witnesses a decrease in their junior year (3.80), yet increases again in their final senior year (3.92). On the constructive dimension, student mean values were the smallest in freshmen (3.8), followed by juniors (4.0), then sophomores (4.03) - and seniors had the highest mean values at (4.05).

To investigate statistically significant differences in the study sample in all four academic years on scale, ANOVA test was conducted and the F-value was calculated, as shown in Table (10), where it is clear that the differences are not statistically significant at $\alpha=0.05$. 
To answer the last question (Is there a correlation between pre-service teachers' beliefs or conceptions regarding the role of the teacher, and understanding the nature of science)? The correlation coefficient was calculated, revealing a statistically significant correlation coefficient at 0.05 on teachers' traditional conceptions on teachers'role and their traditional and constructive conceptions on understanding the nature of science $(0.287,0.309$ respectively).

\section{DISCUSSION}

Findings have exhibited that student teachers have many strongly formed beliefs and conceptions on teaching science and the roles of teachers in it, as the conceptions of preservice teachers were categorized into traditional, constructive, or neutral, with mean values of $4.27,4.40$, and 4.34 respectively, which indicates that the sample usually had a blend of all three. The first three items in the traditional dimension, which assert that the role of the teacher is to provide students with a safe learning environment, steer them toward achieving their appointed objectives, and provide them with the necessary scientific knowledge to achieve that, had the highest mean values.

Concurrently, pre-service teachers displayed constructive conceptions and had high mean values on the 6th, 7th, 8th, and 10th items which point toward encouraging students to participate in the learning process and providing them with the much-needed opportunities to explore and create a constructive learning environment, as well as facilitating and aiding the learning. Furthermore, participants also displayed neutral conceptions, which emphasize the importance of engaging students in entertaining and fun activities during class, as well as the importance of self-development in teachers' science teaching skills.

Teacher conceptions on teaching have further been explored through a question (item) inquiring about the procedures a teacher would be willing to engage in when his or her students are experiencing trouble in understanding a certain scientific concept. The results indicated that a great percentage of teachers might resort to methods that are constructive in their nature, such as using alternate teaching methods, which include playing, hands-on experimentation, taking part in activities or field trips, or implementing technology, etc. (82\%), or to using a more traditional approach, which includes repeating the lesson using the same approach (80\%). The existence of a mix of both conceptions in pre-service teachers could be due to the previous experiences gained during childhood back in their school years, where they were influenced by the practices of their previous teachers.

These findings are consistent with a number of studies including Al-Omary (2006), which showed that $47 \%$ of science teachers held on to a mixture of traditional and constructive beliefs on teaching, and Ankoush (2014) which indicated that 59\% of the sample had a mixture of traditional and constructive beliefs on learning and teaching science. However, these findings were incompatible with those of Tsai (2002), which found that the majority of teachers had traditional beliefs.

Additionally, findings indicated that there were no statistically significant differences in preservice teacher conception toward teacher roles and understanding of nature of science in relation to their university major or their academic year of study.

It may be evident that a single course on teaching methods of science is not sufficient for changing the conception of pre-service teachers on teaching science, since there are no notable changes in their conceptions as they advance through their university programs. This clearly shows that teacher preparation programs did not amount to any major alterations in the 
conceptions of pre-service teachers on teaching, and may lead pre-service teachers toward adopting a traditional teaching approach when practicing their careers later. Yilmaz-Tuzun (2008) asserts that teachers are more inclined toward flashing back when practicing teaching, as they tend to rely on their previous conceptions toward teaching that were formed during their own school years - these conceptions may influence the ideas they develop later in their university years. If pre-service teachers believed that science is taught effectively using traditional approaches, then they become incapable of developing the necessary set of skills required for teaching constructively, and will tend to use traditional methods more frequently when teaching in the future.

Findings concerning the understanding of the nature of science reveal that pre-service teachers possess a mixture of traditional and constructive beliefs, as the study sample had a mean value of 4.00 on the constructive dimension, but of 3.85 on the traditional dimension. These findings are consistent with a number of previous studies, which include Al-Hamaideh (2013), which indicated that Palestinian university students also have a mixture of constructive and traditional conceptions on the nature of science; in addition, Al-Omary (2006) indicated that $41 \%$ of the study sample also had a mixture of constructive and traditional conceptions regarding the nature of science.

This could be due to the lack of sufficient courses tackling the NOS in pre-service teacher preparation programs, as students majoring in these fields are only attend one course in science teaching methods which only briefly discusses the nature of science. In addition, science courses taught in the elementary and secondary schools could be at fault, as they do not tackle the nature of science broadly nor sufficiently.

Furthermore, the previous conceptions held by prospective teachers could play a role in shaping their beliefs and conception, as studies have shown that these are formed during students' school years (Yilmaz-Tuzun, 2008), and could be nurtured and drilled into their minds. These perceptions may be formed through observation of the teachers who taught them in school or through studying textbooks that may include text, graphics and illustrations which could reinforce either traditional or constructive conceptions about teaching science and the nature of science. Teacher preparation programs might not work toward changing these conceptions and beliefs.

Moreover, results in the current study have not pointed toward any significant differences in the levels of understanding the nature of science in pre-service teachers in either majors, which could be due to the fact that both majors only offer a single course in science teaching methods, that all students are subject to very similar teaching experiences, and that all students are present in the same cultural environment.

Courses which tackle teaching methods in teacher-preparation programs are of utmost importance, meaning that the science-teaching courses taught at universities should rather encourage students to adopt constructive teaching methods, set applicable plans for teaching scientific concepts to their students, and provide them with the opportunity to explore their points of strength and weakness in hopes of improving their teaching practices in their future careers, especially that a large portion of the study sample believe they will encounter much difficulty when teaching science in the future. 


\section{RECOMENDATIONS}

1. Conducting a thorough review of Class Teacher and Kindergarten Teacher preparation programs in Jordan to ensure that they provide students with dialogue, to allow the opportunity to discuss and practice critical and reflective thinking, and to assist them in acquiring constructive conceptions on learning and teaching science and understanding the nature of science.

2. Ensuring the implementation of constructive approach in pre- and in-service teacher programs.

3. Conducting research, which explores possible correlation between teachers' conceptions and their classroom practices.

4. Exploring the extent to which teacher preparation programs in Jordan show interest in pre- and in-service teachers' beliefs and conceptions.

5. Conducting studies which examine the sources or causes of such conceptions.

6. Exploring the conceptions held by lecturers at universities as well as by preparation program administrators.

\section{References}

Al-Amoush, S., Usak, M., Erdogan, M., Markic, S., \& Eilks, I. (2013).Pre-service and in-service teachers' beliefs about teaching and learning chemistry in Turkey. European Journal of Teacher Education, 36(4), 464-479.

http://dx.doi.org/10.1080/02619768.2013.807793

Al-Omary,A(2006) Science teacher beliefs about the nature of science,teaching and learning and their relationship to classroom practice (doctoral dissertation, Amman Arab University)

Ankoush, I ( 2014) .Palestinian Science Teachers' Beliefs of Learning: The Origins and Sources of these Beliefs.(Master dissertation, Birzeit University)

Az-Zadajali, A(2006).Science teachers' beliefs on teaching in light of the constructive theory and how it relates to classroom Practices. (Master dissertation, Sultan Qaboos University,Oman.

Bahcivan, E., \& Kapucu, S. (2014). Turkish Pre-service Elementary Science Teachers' Conceptions of Learning Science and Science Teaching Efficacy Beliefs: Is There a Relationship?. International Journal of Environmental and Science Education, 9(4), 429-442.

Celik, S., \& Bayrakceken, S. (2012).The influence of an activity-based explicit approach on the Turkish prospective science teachers' conceptions of the nature of science. Australian Journal of Teacher Education, 37(4), 6.DOI10.14221/ajte.2012v37n4.3

Chan, K. W., Tan, J., \& Khoo, A. (2007). Pre-service teachers' conceptions about teaching and learning: a closer look at Singapore cultural context.Asia-Pacific Journal of Teacher Education, 35(2), 181-195.

http://dx.doi.org/10.1080/13598660701268593

Chang, W. H. (1998). Factors Impeding In-service Teachers from Adopting Constructivist Instruction Approaches

Desli, D., \& Dimitriou, A. (2013). Teaching mathematics and science in early childhood: prospective kindergarten and primary school teachers' beliefs. Review of Science, Mathematics and ICT Education, 8(2), 25-48.

Gao, L., \& Watkins, D. A. (2002). Conceptions of teaching held by school science teachers in PR China: Identification and cross-cultural comparisons. International Journal of Science Education, 24(1), 61-79. http://dx.doi.org/10.1080/09500690110066926

Hamaideh ,A( 2013):Understanding of Nature of Science by Third and Fourth Year Students

in Faculties of Science in Palestinian Universities(master dissertation, Birzeit University)

The influence of K-12 field experiences. Journal of Science Teacher Education, 15(4), 281-291.

Hancock, E. S., \& Gallard, A. J. (2004). Pre-service science teachers' beliefs about teaching and learning. DOI: 10.1023/B:JSTE.0000048331.17407.f5

Harlen, W. Teaching, learning and assessing science 5-12.Sage Publications, 2006. 
Hashweh, M. Z. (1996). Effects of science teachers' epistemological beliefs in teaching. Journal of Research in Science teaching, 33(1), 47-63.

Ibrahim, l.(2005).The status of science teaching in the first three primary grades in Jordan and means of its development in view of current trends in science education.

(doctoral dissertation, Amman Arab University)

Levitt, K. E. (2002). An analysis of elementary teachers' beliefs regarding the teaching and learning of science. Science education, 86(1), 1-22. DOI: 10.1002/sce.1042

Pajares, M. F. (1992). Teachers' beliefs and educational research: Cleaning up a messy construct. Review of educational research, 62(3), 307-332. doi: 10.3102/00346543062003307

Porlán, R., \& Del Pozo, R. M. (2004).The conceptions of in-service and prospective primary school teachers about the teaching and learning of science. Journal of science teacher education, 15(1), 39-62. doi:10.1023/B:JSTE.0000031462.40615.56

Savasci-Acikalin, F. (2009, June). Teacher beliefs and practice in science education. In Asia-Pacific Forum on Science Learning and Teaching (Vol. 10, No. 1, pp. 1-14).Hong Kong Institute of Education. 10 Lo Ping Road, Tai Po, New Territories, Hong Kong.

Skamp, K., \& Mueller, A. (2001).Student teachers' conceptions about effective primary science teaching: A longitudinal study. International Journal of Science Education, 23(4), 331-351.

Tsai, C. C. (2002). Nested epistemologies: science teachers' beliefs of teaching, learning and science. International journal of science education, 24(8), 771-783.

http://dx.doi.org/10.1080/09500690110049132

Yilmaz-Tuzun, O. (2008). Pre-service elementary teachers' beliefs about science teaching. Journal of Science Teacher Education, 19(2), 183-204. DOI: 10.1007/s10972-007-9084-1 